\title{
Crimes tributários, parcelamentos e extinções de punibilidade: ataque à Constituição Federal? *
}

\section{TAX CRIMES, SUB-DIVISIONS AND PUNISHMENT TERMINATION: ATTACK TO THE FEDERAL \\ Constitution?}

\author{
Maria Fádua Lima Rocha ** \\ Nestor Eduardo Araruna Santiago ***
}

Resumo: Este trabalho busca analisar o tratamento constitucional da extinção da punibilidade nos crimes tributários em face do pagamento integral dos tributos sonegados ou da suspensão da pretensão punitiva pela sua inclusão em programas de parcelamento. Adotou-se a pesquisa bibliográfica e documental. Constatou-se que a política tributária nacional, concretizada pela regularidade de privilégios explícitos, estimula a inadimplência e o autofinanciamento de criminosos com recursos públicos, e que o tratamento privilegiado dispensado à criminalidade tributária agride a ordem constitucional brasileira, impedindo a distribuição de riqueza e violando o princípio da capacidade contributiva.

Palavras-chave: Crimes tributários. Extinção de punibilidade. Constituição Federal. Capacidade contributiva.

Abstract: This paper analyzes the constitutional treatment of the punishing termination of tax crimes punishable due to full payment of the taxes evaded or the suspension of the punitive

* Artigo convidado. ** Especialista em Direito Tributário pela Unifor. Auditora Fiscal da Receita Federal do Brasil. Lotada na Delegacia da Receita Federal do Brasil em Fortaleza. E mail: mfadualr@yahoo.com.br *** Doutor em Direito. Professor do Programa de PósGraduação em Direito Constitucional da Universidade de Fortaleza (UNIFOR). Professor Universidade Federal do Ceará (UFC). Assessor Jurídico do Tribunal de Justiça do Estado do Ceará. E-mail: nestorsantiago@globo.com claim for their inclusion in programs for sub-division. It was adopted the literature and document research. It was found that the national tax policy, expressed by the regular explicit privileges, stimulates the default and cash flows of criminals with public funds, and that the preferential treatment oriented to tax criminality attacks the Brazilian constitutional order by preventing the distribution of wealth and violating the principle of ability to pay.

Keywords: Tax crimes. Punishing termination. Brazilian Federal Constitution. Ability-to-pay principle. 


\section{INTRODUÇÃO}

A exclusão da punibilidade mediante o pagamento é, em termos de política tributária, aceitável, desde que não se transmude em beneficio ilimitado. A realidade, contudo, tem transformado a extinção da punibilidade pelo pagamento integral ou em parcelas em privilégio odioso, dissonante do principio da igualdade, privilegiando a inadimplência sistemática e o autofinanciamento de sonegadores com recursos públicos, os quais deveriam financiar os fins sociais do Estado brasileiro previstos na Constituição Federal (CF).

Este trabalho pretende reforçar a discussão acerca da extinção da punibilidade pelo pagamento nos crimes contra a ordem tributária. Nesse contexto, busca promover a compreensão do modelo de Estado Fiscal e Social disciplinado na $\mathrm{CF}$, bem como apresentar a justificativa da arrecadação de tributos como meio legitimo para o Estado Social atingir sua finalidade.

Vale lembrar que referidos parcelamentos são favores fiscais postos à disposição dos contribuintes que, por motivos eventuais e alheios à sua vontade, tornam-se inadimplentes para com o Estado durante determinado lapso de tempo. Uma medida excepcional que vem em socorro do contribuinte, proporcionandolhe a regularização de uma situação esporádica e anormal.

Para a concretização dos objetivos, optou-se pela adoção da pesquisa bibliográfica, bem como a documental, com utilização da legislação pertinente ao tema da extinção da punibilidade e da jurisprudência já produzida em torno da temática objeto deste estudo.

Os resultados obtidos na pesquisa distribuem-se em dois tópicos, o primeiro dos quais aborda a minimização da punibilidade nos crimes contra a ordem tributária como geradora de inadimplência e sonegação, enquanto o segundo é dedicado a analisar a higidez da ordem constitucional pátria defronte da concessão quase indiscriminada do benefício.

\section{CONCESSÃO DE PARCELAMENTOS: ESTÍMULO À INADIMPLÊNCIA E À SONEGAÇÃO?}

Ecoa o art. 155-A do Código Tributário Nacional (CTN), acrescido pela Lei Complementar n. 104/2001, que "o parcelamento será concedido na forma e condição estabelecidas em lei especifica".

Nesse sentido, frequentemente são concedidos parcelamentos especiais a entes públicos e empresas privadas, além das pessoas físicas, somando-se às 
já existentes modalidades de parcelamento comum em 60 (sessenta) meses, que independem de momento específico.

Para as pessoas físicas e jurídicas de direito privado, os principais, desde 2000, foram o Programa de Recuperação Fiscal (REFIS), em 4 edições, chamadas de REFIS I; REFIS II ou Parcelamento Especial (PAES); REFIS III ou Parcelamento Excepcional, (PAEX); e, por último, REFIS IV ou "Refis da Crise", pois foi editado logo após o estouro da bolha financeiro-imobiliária dos Estados Unidos da América, com repercussões moduláveis pelo mundo. Já para as pessoas jurídicas de direito público, a lista de privilégios fiscais é bem mais extensa.

Objetivando resguardar o patrimônio da Seguridade Social, a Lei no 8.212/ 91 previa, em seu art. 38, o parcelamento dos débitos fiscais em até 60 (sessenta) parcelas. Nesse parcelamento, contudo, não poderiam constar as contribuições descontadas dos segurados, nem as decorrentes de sub-rogação. O acordo só seria travado após o pagamento integral do débito parcelado. Nada mais justo, uma vez que as citadas contribuições não repassadas à previdência social configuram a hipótese delituosa prevista no art. 168-A do Código Penal (CP).

Igualmente, prevê a Lei n. 10.522/2002 parcelamento convencional em até 60 (sessenta) parcelas e a vedação de inclusão de débitos passiveis de retenção, de descontos ou de sub-rogação.

Ocorre que a Lei n. 11.941/2009, oriunda da conversão da Medida Provisória (MP) n. 449/2008, revogou o parcelamento da Lei n. 8.212/91, introduzindo diversas alterações no parcelamento albergado na Lei n. 10.522/ 2002. Não é custoso mencionar, outrossim, que as alterações promovidas ofereceram condições mais benéficas aos contribuintes inadimplentes.

A Lei n. 12.382, de 25 de fevereiro de 2011, inseriu ao art. 83 da Lei n. 9.430, de 27 de dezembro de 1996, seis parágrafos os quais passaram a dispor ordinariamente, a exemplo de legislações concessivas de parcelamentos especiais, acerca da extinção da punibilidade pelo parcelamento do crédito tributário, desde que ele tenha sido requerido antes do recebimento da denúncia criminal e o débito referido integralmente pago, sob pena de sua exclusão do parcelamento e encaminhamento da representação fiscal para o Ministério Público.

Constatar-se-á, na esteira da evolução legislativo-tributária, o mesmo intuito "humanista" observado na legislação penal que regula os crimes praticados contra a ordem tributária. Continuamente têm sido lançados programas especiais de parcelamento, que, como destacado na ADI n. 4.273 pelo Procurador da 
República Douglas Fischer, reforçam “a percepção da dupla balança da Justiça: a penalização sistemática dos delitos dos pobres e a complacência com os delitos dos ricos" (2011, online), transformando esse instrumento excepcional em um contumaz estímulo à sonegação.

\subsection{Cronologia dos parcelamentos especiais}

O REFIS instituído pela Lei n. 9.964/2000 albergou débitos de tributos e contribuições administrados pela Secretaria da Receita Federal (SRF) e pelo Instituto Nacional do Seguro Social (INSS) com vencimento até 29 de fevereiro de 2000, e opção formalizada até o último dia útil de abril de 2000.

Os débitos inseridos poderiam estar constituídos ou não, inscritos ou não em divida ativa, ajuizados ou a ajuizar, com exigibilidade suspensa ou não, incluídos, ainda, os decorrentes de falta de recolhimento de valores retidos (descontados dos segurados e não repassados à previdência social). Não foi fixado prazo para a quitação do débito, apenas as parcelas ficaram limitadas a no máximo $1,5 \%$ (um e meio por cento) do faturamento da empresa.

O débito consolidado sujeitar-se-ia a juros correspondentes à variação mensal da Taxa de Juros de Longo Prazo (TJLP). A opção ficaria condicionada à prestação de garantia ou arrolamento de bens.

A pretensão punitiva do Estado referente aos crimes previstos nos arts. $1^{\circ}$ e $2^{\circ}$ da Lei n. 8.137/1990 e no art. 95 da Lei n. 8.212/1991 ficaria suspensa durante o período em que os débitos relacionados com o agente dos aludidos crimes estivessem incluídos no REFIS se a inclusão tivesse ocorrido antes do recebimento da denuncia criminal, não correndo a prescrição criminal durante o período de suspensão da pretensão punitiva. $O$ pagamento integral dos débitos antes do recebimento da denúncia formulada pelo MP extinguiria a punibilidade dos aludidos crimes.

A regularidade no pagamento dos tributos seria condição para manter-se no programa de recuperação fiscal. A exclusão do contribuinte devedor do REFIS implicaria exigibilidade imediata da totalidade do crédito tributário suspenso. O prazo para adesão foi reaberto por mais 90 (noventa) dias pela Lei n. $10.002 / 2000$.

Pouco tempo depois foi publicada a Lei n. 10.684/2003, instituindo novo parcelamento especial amparando igualmente os débitos constituídos ou não, inscritos ou não em Divida Ativa, mesmo em fase de execução fiscal ajuizada, e também aquele objeto de parcelamento anterior, não integralmente quitado ou 
até mesmo rescindido por falta de pagamento. Os tributos, dessa feita, poderiam ser parcelados em até 180 (cento e oitenta) prestações mensais e sucessivas.

A atualização das parcelas dar-se-ia também pela variação mensal da TJLP. A opção por esse novo parcelamento excluiria a concessão de qualquer outro, extinguindo-se, assim, os anteriormente concedidos, admitida, no entanto, a transferência de seus saldos para a nova modalidade que se instituiu. Iniciouse, aqui, a ciranda das migrações dos parcelamentos.

Há que se mencionar como inovações no novo programa que a composição do parcelamento albergaria somente as contribuições previdenciárias patronais com vencimento até 28 de fevereiro de 2003, restando excluídas do beneficio as descontadas dos segurados ou retidas. A apresentação de garantia ou de arrolamento de bens não foi exigida. As multas, de mora e de oficio, foram reduzidas em $50 \%$ (cinquenta) por cento.

Permaneceria suspensa a pretensão punitiva do Estado referente aos crimes previstos nos arts. $1^{\circ}$ e $2^{\circ}$ da Lei n. 8.137/1990 e 168-A e 337-A do CP durante o período em que os débitos relacionados com o agente dos aludidos crimes permanecessem parcelados. Do mesmo modo, não correria a prescrição criminal durante o período de suspensão da pretensão punitiva. $\mathrm{O}$ pagamento integral dos débitos, a qualquer tempo, no entanto, extinguiria a punibilidade dos aludidos crimes, revelando-se, aqui, a grande e benéfica novidade desse PAES.

A rescisão do parcelamento impossibilitaria a concessão de qualquer outra modalidade de parcelamento até 31 de dezembro de 2006. Ocorre que, antes mesmo de findar esse prazo novo parcelamento especial fora concedido, o excepcional (PAEX) previsto na Medida Provisória (MP) n. 303, de 29 de junho de 2006.

A citada MP contemplou duas modalidades de parcelamento: em até 130 (cento e trinta) prestações mensais e sucessivas, para os débitos com vencimento até 28 de fevereiro de 2003, e em até 120 (cento e vinte) prestações mensais e sucessivas, para aqueles com vencimento entre $1^{\circ}$ de março de 2003 e 31 de dezembro de 2005.

Para a opção em 130 (cento e trinta) parcelas, as multas de mora e de oficio sofreriam redução de $50 \%$ (cinquenta por cento), atualizadas pela TJLP. Já para a opção em 120 (cento e vinte) parcelas, a atualização das parcelas dar-se-ia pela taxa do Sistema Especial de Liquidação e de Custódia (SELIC). $\mathrm{O}$ beneficio excluiu os impostos e contribuições retidos na fonte ou descontados de terceiros e não recolhidos à Fazenda Nacional ou ao INSS. 
Os débitos incluídos nos parcelamentos especiais REFIS e PAES e nos convencionais poderiam compor o novo parcelamento, que abrigaria seus saldos remanescentes, transferidos para a nova modalidade. $O$ pagamento à vista ou parcelado, excepcionalmente, em seis parcelas, gozaria do benefício da redução de $80 \%$ (oitenta por cento) das multas de mora e de oficio, e de $30 \%$ (trinta por cento) dos juros de mora.

Referida MP, não sendo convertida em lei, perdeu sua eficácia em 27 de outubro de 2006.

Fechando quase uma década de benesses fiscais, a MP n. 449, de 3 de dezembro de 2008, instituiu novas modalidades de parcelamento ordinário e concedeu remissão aos débitos para com a Fazenda Nacional, inclusive os com exigibilidade suspensa, iguais ou inferiores a $\mathrm{R} \$ 10.000,00$ (dez mil reais) que, em 31 de dezembro de 2007, estivessem vencidos há cinco anos ou mais.

Para que se pudesse obter a redução das multas e dos juros, o parcelamento deveria ser fixado entre seis e vinte e quatro parcelas, tendo o número de parcelas influência direta na redução. Sem nenhuma redução de multas, juros ou de encargos legais, os fatos geradores ocorridos até 31 de maio de 2008 poderiam ser parcelados em até 60 (sessenta) ou 120 (cento e vinte) meses, desde que a primeira parcela correspondesse a, no mínimo, $30 \%$ (trinta por cento) do montante dos débitos consolidados.

Com a conversão da citada MP na Lei n. 11.941, de 27 de maio de 2009, pode-se dizer que o espírito "humanista" se instalou definitivamente na Administração Pública. Afinal, passou-se a proporcionar aos inadimplentes e também aos sonegadores pessoas físicas e jurídicas - um benefício fiscal em até 180 (cento e oitenta) parcelas, englobando os débitos administrados pela Secretaria da Receita Federal e Procuradoria Geral da Fazenda Nacional (PGFN), constituídos ou não, inscritos ou não em dívida ativa da união, mesmo em fase de execução fiscal ajuizada, os decorrentes de apuração indevida de Imposto sobre Produtos Industrializados (IPI), os saldos remanescentes dos parcelamentos especiais REFIS/PAES/PAEX e dos convencionais das Leis n. $8.212 / 91$ e n. $10.522 / 2002$, bem como os dos optantes dos parcelamentos das MP nº 303/2006 e 449/2008, mesmo quando excluídos por falta de pagamento.

A conversão proporcionou a inclusão de débitos vencidos até $30 \mathrm{de}$ novembro de 2008, prorrogando-se a inclusão dos fatos geradores por mais seis meses. O novo parcelamento foi dividido em duas modalidades: i) débitos 
que não foram objeto de parcelamentos anteriores; e ii) débitos anteriormente parcelados. Mantendo a tônica original, os descontos das multas e juros oscilaram em função da opção pelo número de parcelas, para a primeira modalidade e para a segunda, em razão do histórico inicial do parcelamento. Aqui, ao contrário do beneficio antecedente, em qualquer opção o contribuinte usufruiria as reduções previstas.

O pagamento integral dos débitos extinguiria a punibilidade dos crimes previstos nos arts. $1^{\circ}$ e $2^{\circ}$ da Lei ${ }^{\circ} 8.137 / 1990$, e 168-A do Código Penal, ficando suspensa a pretensão punitiva do Estado em relação aos mesmos crimes, enquanto estiverem parcelados os débitos e desde que o mesmo tenha sido efetuado em momento anterior ao oferecimento da denúncia. Enquanto suspensa a pretensão punitiva, a prescrição criminal não correria contra o agente do delito.

$\mathrm{O}$ acesso ao beneficio independe de garantia ou de arrolamento de bens. A permanência no parcelamento garante a amortização do saldo devedor com as reduções previstas para o pagamento à vista do débito. $\mathrm{O}$ prazo para opção encerrou-se no último dia útil de novembro de 2009.

Ressalta-se que os benefícios penais previstos nos artigos 67, 68 e 69 da citada lei, a exemplo da ADI n. 3.002-DF, que contestou a constitucionalidade do art. $9^{\circ}$ da Lei ${ }^{\circ} 10.684 / 2003$ (PAES), encontram-se com sua constitucionalidade sob ataque pela ADI n. 4.273, por também suspender, no caso de adesão ao parcelamento respectivo, a ação penal por prazo incerto e não sabido, contrariando, assim, dentre outros, os princípios constitucionais da moralidade pública, proporcionalidade (sob a perspectiva da proteção deficiente) e igualdade.

Como se disse linhas atrás, a edição da Lei n. 12.382/2011, de uma certa forma, procurou diminuir os efeitos da extinção da punibilidade pelo parcelamento integralmente pago, bem como ao pagamento sem parcelamento, estipulando marco temporal anteriormente adotado pela legislação brasileira: o recebimento da denúncia criminal pelo juízo competente.

Humanizar-se a punibilidade dos crimes tributários pela suspensão da pretensão punitiva Estatal em decorrência do parcelamento do crédito tributário é um atentado à ordem constitucional contemporânea pela incoerência do conteúdo legal dos atacados dispositivos legais com os princípios constitucionais incondicionalmente garantidores de direitos básicos ou fundamentais aos indivíduos, como se pretende visualizar na sequência. 


\subsection{A "humanização" da punibilidade nos delitos tributários pela consagração de privilégios minimizadores de sua gravidade}

A relação de adequação e subordinação da lei a um espectro normativo mais elevado condiciona o legislador ordinário a conter a sua produção legislativa no perímetro da conformidade com a ordem constitucional existente, no que se chama de filtragem constitucional.

A constante edição de normas penais tributárias consagrando privilégios à sonegação fiscal afronta a ordem constitucional brasileira na medida em que minimiza delitos que, por sua gravidade, inviabilizam o projeto de erradicação da pobreza e redução das desigualdades sociais.

A extinção da punibilidade pela comprovação do pagamento integral do débito tributário, ensejando o trancamento da ação penal, desde muito encontra previsão na legislação brasileira. Leis posteriores à n. 4.729/65, que foi a primeira lei brasileira a cuidar da extinção da punibilidade nos crimes tributários, revogaram e fizeram ressurgir o beneficio, criando novos prazos limites para a efetuação do pagamento, como é o caso da Lei n. 9.983/2000, que condicionou o pagamento a período anterior ao inicio da ação fiscal, aceitando de modo condicional o pagamento feito após o inicio da ação fiscal e antes do recebimento da denúncia.

A concessão de parcelamento é um favor fiscal colocado à disposição dos contribuintes que, por motivos eventuais e alheios a sua vontade, tornam-se inadimplentes para com o Estado durante determinado período de tempo.

$\mathrm{O}$ estimulo ao contribuinte infrator a regularizar suas pendências fiscais encontra previsão expressa no art. 138 do Código Tributário Nacional (CTN), dispositivo legal que estimula o cumprimento das obrigações tributárias, afastando a responsabilidade por infrações somente pelo reconhecimento e cumprimento espontâneo da obrigação. O sistema penal tributário deve manter-se rígido, não advindo dele nenhum estimulo à inadimplência.

Amaro (2007, p.468) entende que a regra do art. 138 do CTN afasta qualquer possibilidade de punição seja de natureza administrativa, seja criminal, desde que o pagamento do tributo seja feito antes do início do procedimento fiscal ou medida de fiscalização relacionados com a infração.

Leis posteriores mantiveram para a fruição do beneficio extintivo o período que antecede a peça acusatória ministerial, lembrando que as mesmas normas preveem a suspensão da pretensão punitiva estatal pelo parcelamento. Descabida e, portanto, imoral a flexibilização de marco processual premiando 
sonegadores com a extinção da punibilidade pelo pagamento e sua suspensão pelo parcelamento.

Entende-se materialmente condenável a criação de norma legal suspendendo ou extinguindo a punibilidade de crimes tributários, uma vez que disposições desse tipo acarretam a diminuição do risco de sonegar, tranquilizando o sonegador, que, assim, passa a contar com um recurso a mais a ser utilizado quando (e se) suas práticas ilícitas forem detectadas pelos agentes fiscalizadores.

De fato, concorda-se com Aveline (2010, online) quando aponta que o ilimitado e frequente roteiro sonegação-fiscalização-pagamento-extinção da punibilidade representa um forte estimulo à delinquência tributária em face da redução do risco de sonegar frente à magnitude dos ganhos patrimoniais advindos do autofinanciamento com recursos públicos. $\mathrm{O}$ autor acrescenta, enfático, que:

O cumprimento do dever legal de pagar tributos no tempo e modo devidos acaba desprovido de qualquer força cogente. Ciente dos privilégios fiscais e penais que reiteradamente a legislação concede e diante das exorbitantes taxas de juros cobradas pelas instituições financeiras, prefere o sonegador financiar-se, com juros e prazo infinitamente superiores, com os tributos que sonega e que deveriam financiar os elevados fins previstos na Constituição Federal. Como consequência disso, os encargos do financiamento dos programas sociais estatais acabam sendo suportados com maior intensidade pelos indivíduos que pagam corretamente os tributos, em especial as classes mais desfavorecidas, que arcam com uma quantidade enorme de tributos indiretos que oneram produtos de primeiríssima necessidade. As demandas sociais sempre crescentes passam a exigir uma arrecadação cada vez maior e que, por conta da sonegação, acaba incidindo sobre uma base cada vez menor, implicando elevação desmedida da carga tributária.

A inserção de privilégios fiscais, acompanhada de sistema punitivo desrespeitador do princípio da fragmentariedade e da subsidiariedade do direito penal, em que delitos de grave danosidade social são transformados em meros ilícitos administrativos, avulta a descrença do cidadão no Estado na medida em que protege grupos econômicos e políticos privilegiados.

A condição de classe do infrator é destacada por Pinto (2001, p. 23) como fator determinante do privilégio, criticando ferozmente a forma de punição destinada aos cidadãos "mais iguais do que outros": 
[...] Existe a contradição explicita por parte daqueles que se espraiam pelo Estado, que permanece silente diante do saque às instituições, realizado habitualmente por seus cidadãos, 'mais iguais do que outros' ou, pelo concurso desses agentes. O poder instituído não pode agir de forma a punir seus 'cidadãos honoríficos', seus negociantes, políticos, banqueiros! Era necessário (re)construir um sistema de penas alternativas harmonizado com o sistema capitalista: penas pecuniárias sem o conseqüente registro em folha penal. Seria ultrajante para um 'benemérito cidadão’ passar por este tipo de humilhação. A multa seria paga pela empresa. A pena privativa de liberdade não era adequada para esses 'desviantes' $[\ldots]$.

Desse modo, a regularidade dos inúmeros privilégios assegurados a sonegadores contumazes indigna a sociedade em razão da impunibilidade dos delitos consequentes, agravando os sentimentos de injustiça e complacência com a sonegação já bastante acentuados no coração de um povo que tem a certeza de viver em um País em que os mais bem aquinhoados financeiramente são também os mais protegidos e beneficiados política e legalmente.

Botelho $(2005$, p.92) assevera que a periodicidade dos benefícios enfraquece a coercibilidade jurídica distanciando o comando normativo do comportamento social e acrescenta:

Vista dessa forma, a relevação de sanções previstas para o descumprimento do comando legal e, pior ainda, o perdão das prestações pecuniárias devidas pelo contribuinte são medidas que, se adotadas reiteradamente, levariam à ineficácia da norma, o que redundaria em sua invalidade até mesmo para a teoria kelseniana.

A proteção ativa da sociedade (art. $3^{\circ} \mathrm{CF}$ ) configurada nos deveres de segurança, de proibição de excessos e omissões legislativas imposta ao Estado só se concretizará pela arrecadação tributária. A necessária e efetiva punição dos crimes tributários ampara-se na justiça distributiva. O objetivo constitucionalmente atribuído aos tributos é a justa e eficaz distribuição de riquezas culminando na promoção de uma sociedade igualitária, fraterna e justa, com a erradicação da miséria e das desigualdades sociais. Nessa ótica, a arrecadação tributaria é basicamente a única forma de assegurarse os objetivos constitucionalmente garantidos, implicando sua inobservância em expressa lesão a direito fundamental. 


\section{A FLEXIBILIZAÇÃO DA EXTINÇÃO DA PUNIBILIADE NOS CRIMES TRIBUTÁRIOS E A ORDEM CONSTITUCIONAL SOB ATAQUE}

\subsection{Exposição do problema}

A CF instituiu uma nova concepção de Estado - o Estado Democrático e Social de Direito - e adotou como um de seus fundamentos a dignidade da pessoa humana.

Dignidade personificada nos objetivos perseguidos pela nova ordem implantada, como os da construção de uma sociedade livre, justa e solidária, da erradicação da pobreza e marginalização, da redução das desigualdades sociais e regionais, assim como nos princípios da inviolabilidade do direito à vida, à liberdade, à igualdade, à segurança e nos direitos sociais e econômicos ali previstos.

A CF assumiu, assim, a função protetora da sociedade, cabendo ao Estado a promoção de uma sociedade justa, fraterna e igualitária, livre da pobreza, marginalização e desigualdades, configurando lesão a direito fundamental a não observância a qualquer um desses deveres protetivos.

A tributação consolidou-se como principal fonte de financiamento dos fins estatais por meio de receitas públicas derivadas. O Estado Fiscal assumiu a função indutora do Estado Social. Essa dimensão é ressaltada por Aveline (2010, online):

[...] É assim que a arrecadação tributária se legitima enquanto instrumento para o Estado atingir sua finalidade. A expressão 'preço da liberdade', agora surge como preço que a sociedade paga para que o Estado, reduzindo as desigualdades, promova a liberdade das camadas mais desfavorecidas. [...] Ao lado do aspecto arrecadatório dos tributos, assume especial relevância, no Estado Social Democrático de Direito, sua função indutora. Com efeito, se dentre as formas de atuação estatal sobressai a tributação, parece coerente a conclusão de que normas tributárias indutoras, longe de serem uma exceção, surgem em obediência ao preceito constitucional da atuação positiva do Estado visando à ampliação do gozo da liberdade.

As noções de solidariedade, igualdade e justiça social, personificadas no pagamento do tributo, fundamentam a exação tributária, garantindo o pleno funcionamento e manutenção dos custos com a realização das funções estatais.

SCIENTIA IURIS, Londrina, v.16, n.2, p.199-216, dez.2012 
Para Derzi (2007, p.17-24, passim), a solidariedade social conduz à ideia de repartição das riquezas para o bem de todos, porquanto o imposto encontra sua legitimação no financiamento da ação do Estado enquanto condição de existência da sociedade. Cervini (22007, p.440) chama isso de princípio da redistribuição de riquezas, em que o Estado beneficiaria setores socialmente pauperizados em razão de políticas sociais ativas, sem prejudicar a capacidade contributiva daqueles que recolheram seus tributos.

Claro, portanto, que o Estado só atingirá sua finalidade por meio da legitima arrecadação tributária. Como conciliar, desse modo, as bases do Estado Social - a proteção das necessidades e a promoção do bem-estar social - com a evasão criminosa inescrupulosamente albergada em privilégios odiosos?

Para Aveline (2010, online), a sonegação deve ser focalizada sob a lente da justiça, em especial da Justiça Fiscal, tendo em vista que o pagamento de tributos é dever fundamental para o financiamento da atuação estatal e, portanto, as consequências que se projetam sobre o tratamento tributário e penal privilegiado comprometem a ordem social preconizada na CF nacional.

Também para Pinto (2001, p.23), em face da gravidade do dano, a análise desses delitos deverá concretizar-se sob a ótica da justiça distributiva e não meramente econômica:

Os crimes, por exemplo, contra a ordem tributária, simbolizam perfeitamente situações que são caracterizadas por um grave dano ou lesividade social intensa, uma vez que atingem toda a sociedade, podendo seus efeitos ser coletivos, difusos e supra-individuais. A sociedade 'destinatária' de prestações positivas por parte do Estado, por ocasião da ação delituosa dos desviantes, deixará de promover as prestações positivas afirmadas constitucionalmente, ao (des)penalizar condutas delituosas ou mantendo um (in)suficiente Direito Penal garantidor dos bens jurídico-penais como a ordem econômica e tributária.

Buscar-se-á demonstrar que a lesividade das condutas criminosas descritas nos artigos. $1^{\circ}$ e $2^{\circ}$ da Lei n. 8.137/1990; 168-A, 334 e 337-A do Código Penal e a abusividade recorrente dessa criminalidade inviabiliza a proteção dos bens jurídicos essenciais aos objetivos fixados na Constituição Federal, merecendo tais crimes tratamento mais severo por possuírem hierarquia superior à criminalidade clássica.

Sob esse prisma, abordar-se-á o ataque a princípios constitucionais por meio da "relativização" ou "humanização" das citadas condutas criminosas 
(extinção/suspensão da punibilidade) pela facilitação do pagamento dos tributos apropriados ou suprimidos.

\subsection{Dos princípios constitucionais violados}

Sendo o direito uno, os princípios constitucionais orientam e condicionam o sentido da ordem jurídica implantada formando um todo unitário e harmônico. Assim, as normas jurídicas obrigam-se a guardar total sintonia com a força indicativa dos princípios.

A forma de governo republicano, dentre outras garantias, assegura a todas as pessoas o direito de só sofrerem tributação em razão dos superiores fins do Estado. É a noção de imposto-solidariedade adotada pela $\mathrm{CF}$, que para Botelho (2005, p.24) é uma autêntica busca por justiça social.

Em idêntico sentido são feitas as ponderações de Carrazza (2007, p.7679), insurgindo-se contra o ataque ao principio republicano pela concessão de vantagens tributárias:

Retornemos da longa digressão para considerar que, diante do principio republicano, é proibida a concessão de vantagens tributárias fundadas em privilégios de pessoas ou categorias de pessoas. Deveras, com o advento da República, foi-se o tempo, entre nós, em que as normas tributárias podiam ser editadas em proveito das classes dominantes, até porque, nela, extintos os títulos nobiliárquicos, os privilégios de nascimento e foros de nobreza, 'todos são iguais perante a lei' $\left(\mathrm{CF}\right.$, art. $\left.5^{\circ}\right)$. Atentemos, a propósito, para este primor de relanço de João Barbalho: 'Não há, perante a lei republicana, grandes nem pequenos, senhores nem vassalos, patrícios nem plebeus, ricos nem pobres, fortes nem fracos, porque a todos irmana e nivela o direito'. Logo, nos dias que ora correm, os tributos, no Brasil, devem ser instituídos e arrecadados sem se ferir a harmonia entre os direitos do Estado e os direitos de cada um do povo. [...] O principio republicano foi confirmado, não é demais repetirmos, com a abolição dos privilégios fiscais dos nobres (que desapareceram com a Proclamação da República), dos eclesiásticos e dos exercentes de determinadas funções públicas (que, afinal, servem ao povo, o único dominus da res publica) Logo, com a República, desapareceram os privilégios tributários de indivíduos, de classes ou de segmentos da sociedade. Todos devem ser alcançados pela tributação.

Conclui que "o princípio republicano leva ao principio da generalidade da tributação, pelo qual a carga tributária, longe de ser imposta sem qualquer critério,

SCIENTIA IURIS, Londrina, v.16, n.2, p.199-216, dez.2012 
alcança a todos com isonomia e justiça" (CARRAZZA, 2007, p.29). O sacrifício econômico suportado pelo contribuinte precisa ser igual para todos os que se acham na mesma situação jurídica, razão pela qual o tributo deve atingir a todos que se achem nas mesmas condições.

Não se pretende desautorizar o tratamento diferenciado alicerçado em critérios justificáveis amparados na $\mathrm{CF}$; o foco, aqui, destina-se à discriminação arbitrária entre contribuintes que se encontrem em situação jurídico-tributária equivalente, em autêntica violação ao princípio da capacidade contributiva.

Apesar de expressamente detalhado na CF, o principio da isonomia tributária encontra-se sob constante ataque, como tão bem relata Ferraz apud Paulsen (2007, p.194):

[...] 11.5. Apesar do reiterado e detalhado princípio da igualdade em matéria tributária, explicitado com eloquência na Constituição de 1988, o sistema tributário brasileiro vem adotando fortíssima tendência a tratar diferentemente os contribuintes, gerando regimes específicos, alíquotas diferenciadas, reduções de base de cálculo, diferimentos, isenções e incentivos, sem que haja explicitação de critérios constitucionalmente eleitos para tais distinções. 11.6. A igualdade exige como regra a uniformidade de tratamento, que haverá de ser aplicada a imensa maioria dos casos, sendo muitíssimo excepcional que se configurem situações justificadoras de tratamento diferenciado. 11.7. Efetivamente o cerne da aplicação do principio da igualdade está na identificação dos critérios legítimos para distinção de categorias em face de cada regra jurídica concreta. Nessas circunstâncias, os estudiosos de direito tributário podem dar-se por meio felizes por contarem com um critério positivo de discriminação, universalmente aceito: a capacidade econômica.

Não se consegue visualizar nos programas de parcelamentos relatados nenhum amparo constitucional para a discriminação eleita. Pelo contrário, porquanto criados para atender interesses políticos de uma classe economicamente privilegiada, os benefícios invertem um critério positivo de discriminação - a capacidade contributiva - tornando-a exatamente o critério garantidor do privilégio. Nesse sentido, a outorga do tratamento diferenciado fica claramente destinada a uma elite minoritária detentora de maior riqueza e capacidade contributiva em detrimento da imensa maioria para a qual se volta o olhar constitucional.

Clara é, em consequência, a ofensa ao principio da capacidade contributiva, para o qual sempre que possível, os impostos terão caráter pessoal 
e serão graduados segundo a capacidade econômica do contribuinte, com a qual a tributação inequivocamente correlaciona-se.

A graduação dos impostos, segundo Paulsen (2007, p.61), variará conforme as demonstrações de riqueza de cada um. Assim, o Estado deve exigir que as pessoas contribuam para as despesas públicas na medida da sua capacidade para contribuir, não devendo nada ser exigido de quem só tem para a sua subsistência (mínimo existencial), pois a tributação não pode implicar confisco para ninguém.

Com a mesma clareza ressalta Carrazza (2007, p.86-87) que o principio da capacidade contributiva hospeda-se nas dobras do principio da igualdade, realizando, no campo tributário, os ideais republicanos, sendo justo e jurídico que quem tem muito pague, proporcionalmente, mais imposto do que quem tem pouco. As pessoas devem pagar impostos na proporção dos seus haveres, ou seja, de seus índices de riqueza.

A capacidade contributiva é também decorrência direta do principio da solidariedade, o que justifica uns pagarem impostos e outros não e, ainda, uns pagarem mais e outros menos. Na realidade a solidariedade fundamenta todo o ordenamento jurídico brasileiro.

A tentativa de descriminalização ou 'minimização' de condutas criminosas penalmente tipificadas também viola o principio da proporcionalidade, sob a perspectiva da proibição da proteção deficiente. $\mathrm{O}$ tema é abordado pelo Ministro Gilmar Mendes no julgamento do RE nº 418.376-MS:

[...] De outro modo, estar-se-ia a blindar, por meio de norma benéfica, situação fática indiscutivelmente repugnada pela sociedade, caracterizando-se típica hipótese de proteção deficiente por parte do Estado, num plano mais geral, e do Judiciário, num plano mais especifico. Quanto à proibição de proteção deficiente, a doutrina vem apontando para uma espécie de garantismo positivo, ao contrário do garantismo negativo (que se consubstancia na proteção contra os excessos do Estado) já consagrado pelo principio da proporcionalidade. A proibição de proteção deficiente adquire importância na aplicação dos direitos fundamentais de proteção, ou seja, na perspectiva do dever de proteção, que se consubstancia naqueles casos em que o Estado não pode abrir mão da proteção do direito penal para garantir a proteção de um direito fundamental.

$\mathrm{O}$ ataque não se restringe aos princípios relatados; a ordem constitucional por inteiro e mais precisamente, a efetividade do principio da dignidade da pessoa 
humana como base da República, a cidadania, a moralidade e eficiência pública, os direitos relativos à saúde, à previdência e à assistência social, encontram-se sob ameaça, direta ou indireta, em face do tratamento privilegiador cometido aos devedores do fisco.

A gravidade social dos danos causados pelos delitos contra a ordem tributária alerta para uma urgente mudança de paradigma, em que se verifique a primazia da tutela social sobre o interesse individual. Não somente a Administração Pública, mas a coletividade como um todo, são minimizadas pela condescendência da atual política criminal.

Depreende-se, por fim, que a sangria proporcionada pelos privilégios oriundos dos benefícios fiscais regularmente introduzidos no ordenamento jurídico visando beneficiar uma determinada classe afronta a CF, o Estado Democrático de Direito e a sociedade brasileira.

\section{CONCLUSÃO}

Constatou-se que a evolução da ordem constitucional brasileira não poderá compactuar com os explícitos privilégios concedidos a "desviantes" de recursos públicos, sendo urgente à sociedade contemporânea a conscientização da danosidade social desses crimes à coletividade e a sua devida repulsa social.

Evidencia-se, ainda, que no atual estágio da sociedade brasileira somente a tributação assegurará a todos existência digna, conforme os ditames da justiça social previstos no art. $170 \mathrm{da} C \mathrm{CF}$, concretizando os objetivos da ordem social - bem-estar e justiça social - preconizados no mesmo diploma.

A criminalidade moderna atinge a sociedade fragilizando a cidadania, na medida que afronta valores constitucionalmente garantidos. É urgente, portanto, que o Direito Penal Tributário assuma impositivamente a função garantidora da justiça distributiva assegurada pelo Estado Fiscal, já que seu bem jurídico está intimamente vinculado à função da Administração Pública como provedora do bem-estar social.

A compatibilização dos valores elementares delineados na Constituição com a justa tutela penal exige adequação da legislação penal à nova realidade social. O relaxamento da tutela punitiva por meio de normas extintivas ou suspensivas da punibilidade retiram a credibilidade da função garantista do Estado Social. De certo modo, esse efeito foi minimizado com a edição da nova Lei n. 12.382/2011, que estabeleceu marco temporal mais restrito para 
a obtenção do parcelamento, pelo que se configura lex gravior, somente eficaz para as condutas praticadas sob sua vigência.

Equivocado, portanto, sustentar-se a satisfação do interesse público no aumento da arrecadação tributária, em decorrência dos citados benefícios fiscais. Na realidade, os parcelamentos especiais comprovam exatamente o contrário, ou seja, o favorecimento potencial a contribuintes já favorecidos por benesses fiscais. $\mathrm{O}$ uso abusivo de normas assecuratórias de privilégios penais tributários a sonegadores contumazes desestimula o pagamento espontâneo de tributos, enfraquece a repressão penal, ridiculariza o sistema fiscal, agravando, por fim, a descrença do cidadão no Estado.

Tipificada a conduta delituosa contra a ordem tributária, a possibilidade de extinção da punibilidade do crime pelo pagamento do tributo deve ser afastada. A manifestação do interesse do contribuinte no cumprimento da obrigação tributária pelo pagamento, no entanto, seria, nos termos do art. 65, III do Código Penal, considerada circunstância atenuante da infração.

Acrescenta-se, ainda, a importância da conscientização coletiva por meio de políticas públicas de educação fiscal, objetivando a adesão espontânea dos contribuintes, o fortalecimento do poder público por intermédio do acirramento e modernização da fiscalização e dos meios de repressão, bem como uma urgente e progressiva reforma tributária focada na diminuição da concentração de renda, gravando mais pesadamente a renda e o patrimônio em detrimento do consumo de bens e serviços, buscando a equidade e o alinhamento aos princípios tributários adotados pela $\mathrm{CF}$.

\section{REFERÊNCIAS}

AMARO, Luciano. Direito Tributário Brasileiro. 13. ed. São Paulo: Saraiva, 2007.

AVELINE, Paulo Vieira. Justiça fiscal e sonegação. Revista AJUFERGS, Porto Alegre, n. 3, p. 237-270, 2007. BDjur. Disponível em <http://

bdjur.stj.gov.br/dspace/handle/2011/18358>. Acesso em: 04. nov. 2010.

BOTELHO, Paula Derzi. Sonegação fiscal e identidade constitucional. Belo Horizonte: Del Rey, 2005. 
CARRAZZA, Roque Antonio. Curso de Direito Constitucional

Tributário. 23. ed. São Paulo: Malheiros Editores, 2007.

CERVINI, Raul. Principios del derecho penal tributario en el estado democrático social de derecho. Revista dos Tribunais, São Paulo, a. 96, v. 857, mar. 2007, p. 437-455.

PAULSEN, Leandro. Direito tributário: Constituição e Código Tributário à luz da doutrina e da Jurisprudência. 9. ed. Rev. Atual. Porto Alegre: Livraria do Advogado; ESMAFE, 2007.

PINTO, Emerson de Lima. A Criminalidade econômico-tributária: a (des)ordem da lei e a lei da (des)ordem: por uma (re)legitimação do direito penal do Estado Democrático de Direito. Porto Alegre: Livraria do Advogado, 2001.

Recebido em: 2011-05-02 Aprovado para publicação em: 2012-12-05

Como citar: ROCHA, Maria Fáuda Lima; SANTIAGO, Nestor Eduardo Araruna. Crimes tributários, parcelamentos e extinções de punibilidade: ataque à Constituição Federal?.Scientia Iuris, Londrina, v.16, n.2, p.199-216 dez. 2012. DOI: 10.5433/21788189.2012v16n2p199. 